Revue de droit comparé du travail et de la sécurité sociale

4 | 2017

English Electronic Edition

\title{
Informal Economy, Social Protection and Transition to the Formal Economy: The Terms of a Debate
}

Jacques Charmes

\section{(2) OpenEdition}

Journals

Electronic version

URL: https://journals.openedition.org/rdctss/2243

DOI: $10.4000 /$ rdctss.2243

ISSN: 2262-9815

Publisher

Centre de droit comparé du travail et de la sécurité sociale

Printed version

Date of publication: 1 December 2017

Number of pages: $58-65$

ISSN: $2117-4350$

Electronic reference

Jacques Charmes, "Informal Economy, Social Protection and Transition to the Formal Economy: The Terms of a Debate", Revue de droit comparé du travail et de la sécurité sociale [Online], 4 | 2017, Online since 01 November 2021, connection on 04 December 2021. URL: http://journals.openedition.org/ rdctss/2243; DOI: https://doi.org/10.4000/rdctss.2243

\section{(c) (†) $\odot$}

Revue de droit comparé du travail et de la sécurité sociale est mise à disposition selon les termes de la Licence Creative Commons Attribution - Pas d'Utilisation Commerciale - Pas de Modification 4.0 International 


\section{INFORMAL ECONOMY, SOCIAL PROTECTION AND TRANSITION TO THE FORMAL ECONOMY: THE TERMS OF A DEBATE}

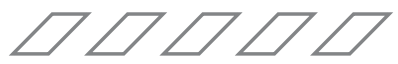

\section{RÉSUMÉ}

Les concepts de secteur informel, d'emploi informel et d'économie informelle continuent à faire l'objet de nombreux contresens, malgré les progrès enregistrés dans leurs définitions internationales. C'est pourquoi il est toujours nécessaire et utile de rappeler les termes de ces définitions internationales qui ont permis des mesures plus précises de ces phénomènes et ont également permis l'adoption de recommandations en vue d'assurer de manière consensuelle la transition de l'économie informelle vers l'économie formelle. Une telle transition passe entre autres par l'universalisation d'une protection sociale assurant la couverture des risques fondamentaux (santé, maternité, retraite ...) qui est inscrite dans les Objectifs du Développement durable.

MOTS-CLÉS : Emploi informel, économie informelle, secteur informel, protection sociale.

\section{ABSTRACT}

The concepts of informal sector, informal employment and informal economy continue to be the subject of many misunderstandings despite progress made in their international definitions. This is why it is always necessary and useful to recall the terms of these international definitions which have enabled more precise measurements of these phenomena and have also made it possible to adopt recommendations with a view to achieving a consensual transition from the informal economy to the formal economy. Such a transition involves, among other things, the universalization of social protection covering the basic risks (health, maternity, old age, etc.) that is enshrined in the Sustainable Development Goals.

KEYWORDS: Informal Employment, Informal Economy, Informal Sector, Social Protection. 
Ithough the term has now been in use for 45 years - since it was in 1971-72 that the term was coined - the concept of the informal economy continues to be the subject of a great deal of confusion and misunderstanding on the part of both economists and politicians. The most common of these misunderstandings is the assimilation of the informal economy with the underground economy, the shadow economy and, ultimately, the illegal "black" economy. And yet if we come back to the origins of the concept, we will note that these activities "are not necessarily performed with the deliberate intention of evading the payment of taxes or social security contributions, or infringing labour legislation or other regulations" to use the terms of the definition adopted in 1993. And, indeed, workers in the informal economy do not operate in the moonlight, but in broad daylight, in full view of everyone. Furthermore, the terms used to describe them in Swahili in Kenya (country where the concept was born in 1971-72) is "Jua Kali", which means "under the burning sun".

In actual fact, more than a deliberate intention by these players to avoid the legislation in force, it is rather of a certain inability or powerlessness of the State to apply its own regulations that we should be talking, either because the latter are profoundly unsuitable, having been modelled on those of the old colonial powers, or because the process of modernisation and industrialisation not having taken hold as they were expected to do so by the optimistic vision of development, the progressive adaptation of the real economy to these regulations has not occurred as quickly as hoped. Which has led to a certain tolerance of these activities, which then breeds rampant corruption that in turn allows them to continue to be practised.

Nevertheless, the constant growth in informal jobs has not failed to put the public authorities face to face with the reflection of their powerlessness, which is all the more devastating that the vitality of the informal economy has as its counterpoint the stagnation or the blockage of a formal sector dominated by a bloated public sector. However, the formal private sector, constricted, has not shied away from reminding the authorities of this unfair competition, which it claims is the cause of its difficulties, and it is true that a fraction of these informal activities is now made up of economic units manifesting their desire to evade existing legislation, and now constitute a part of this sector. Few countries are willing to admit or recognise the existence of an informal economy such that it would merit a comprehensive raft of policies being dedicated to it. Instead they favour more positive, less loaded terms: self-employment, micro-businesses, artisan activities and small trades, income-generating activities, etc.

The fact remains that the jobs in question have all the characteristics of precarious employment. The International Labour Organisation (ILO) which, in a period when 
unemployment and underemployment were beginning their seemingly inexorable rise, had put the emphasis on the positive aspects and vitality of these activities, (after the groundbreaking report on employment in Kenya ${ }^{1}$ ) then on promoting independent employment, ${ }^{2}$ came next to present the issue in the form of a dilemma ${ }^{3}$. After that the ILO came to define the terms of decent job, ${ }^{4}$ to lay the principle of the social protection floors ${ }^{5}$ and, finally, as part of its tripartite vocation (organising the dialogue and consensus between governments, employers and workers), to unanimously adopt, in 2015, a recommendation with a view to facilitating the transition from the informal economy to the formal economy. ${ }^{6}$ Now the expansion of universal social protection, which is the third target of the first of the Sustainable Development Goals (SDG) and is reiterated among the targets of other SDGs (health, gender equality, reduced inequalities), is one of the paths that the process of transition towards the formal economy must take.

After recalling the definitions of the informal economy and its main components (I), we will examine the potential for expanding social protection to these activities (II) and then try to re-situate this approach within the wider framework of the strategies for transitioning from the informal to the formal economy (III).

\section{I - DEFINITIONS OF THE INFORMAL ECONOMY}

From the outset, there have been two opposing, or rather to some extent complementary conceptions of this notion. The first - which came in the wake of the ILO report on Kenya ${ }^{7}$ - defines informality by the characteristics of the enterprise in which the person works; the second defines the phenomenon - following on from Keith Hart, ${ }^{8}$ who talked about "informal income opportunities" - by the characteristics of the job occupied by the person.

It was the first conception that initially prevailed, leading to the first definition of the informal sector in 1993. The $15^{\text {th }}$ International Conference of Labour Statisticians ICLS), in

$1 \quad$ ILO, Employment, Incomes and Equality. A Strategy for Increasing Productive Employment in Kenya. ILO, Geneva, 1972.

2 ILO, Promotion of self-employment, Report of the Director-General, International Labour Conference, 77th session, Geneva, 1990

3 ILO (1991), The Dilemma of the Informal Sector, Report of the Director-General, International Labour Conference, 78th session, Geneva, 1991

4 ILO (1999), Decent Work, Report of the Director-General, International Labour Conference, 87th session, Geneva, 1999. ILO, Decent work and the informal economy, International Labour Conference, 90th session, Geneva, 2002

5 ILO, Recommendation 202 - Recommendation on Social Protection Floors, adopted by the Conference at its hundred and first session, Geneva, 14 June 2012.

$6 \quad$ ILO,Transitioning from the Informal to the Formal Economy, International Labour Conference, Report V (1), 103rd session, 2014. ILO, Recommendation 204 - Recommendation on the Transition from the Informal to the Formal Economy, adopted by the Conference at its hundred and fourth session, Geneva, 12 June 2015.

$7 \quad \mathrm{ILO}$, Employment, Incomes and Equality. A Strategy for Increasing Productive Employment in Kenya, ILO, 1972, Geneva.

8 Hart, K., «Informal Income Opportunities and Urban Employment in Ghana», Journal of Modern African Studies, 1971, vol. II 
charge of defining labour force concepts, adopted a Recommendation to this effect in $1993 .{ }^{9}$ This recalls that the informal sector consists of a set of units producing goods and services mainly with a view to generating employment and income for the people concerned, units with a low level of organisation, operating with little or no division between labour and capital, on a small scale, and with labour relations, if any exist, based on casual employment, kinship or personal/social relations rather than contracts with formal guarantees. More concretely, it involves production units consisting of individual enterprises (as opposed to corporated and quasi-corporated enterprises which keep a complete set of accounts, or associations) and as such, belonging to the institutional sector of households in the national accounts. They are comprised of own-account workers who may employ family workers and employees on an occasional basis, and of informal employers who employ one or more employees on a continual basis, below a certain threshold (generally 5 employees), and/or without registering them and/or without being registered as an enterprise.

This definition was applied in numerous surveys from 1993 onwards and gave rise to policies supporting self-employed workers and micro-enterprises in many developing countries.

However, the adoption of this definition did not render invalid for all the conception of informality based on the characteristics of the job, especially in view of the way globalisation was leading to an expansion of the processes of subcontracting, home-based working, outsourcing and increased job insecurity, which meant that the 1993 definition appeared to cover only a part, even though it may be a sizeable part, of the process of informalisation.

This is why in 2003 the $17^{\text {th }} I C L S^{10}$ would propose a set of guidelines for defining informal employment. Informal employment covers workers and specifically employees "whose employment relationship is, in law or in practice, not subject to national labour legislation, income taxation, social protection or entitlement to certain employment benefits (advance notice of dismissal, severance pay, paid annual or sick leave, etc.). The reasons may be the following: non-declaration of the jobs or the employees; casual jobs or jobs of a limited short duration; jobs with hours of work or wages below a specified threshold (...); jobs where the employee's place of work is outside the premises of the employer's enterprise (e.g. outworkers without employment contract); or jobs, for which labour regulations are not applied, not enforced, or not complied with for any other reason". Also covering nonsalaried workers, this definition boils down - and takes the form of this question in surveys - to the absence of social protection or the non-payment of social contributions (especially for health coverage).

Far from rendering the 1993 definition of employment in the informal sector obsolete, the 2003 definition of informal employment completes it.

Ultimately, the two definitions are not mutually exclusive and in fact partly overlap, so that what is commonly called employment in the informal economy includes several components: 1) employment in the informal sector, 2) informal employment in the formal sector, 3) informal domestic workers, and finally 4) people engaged in household production

9 ILO, Statistics of employment in the informal sector, Report for the 15th International Conference of Labour Statisticians, Geneva 19-28 January 1993. ILO, Report of the Conference, Report for the 15th International Conference of Labour Statisticians, Geneva 19-28 January, ILO

10 ILO, 17th International Conference of Labour Statisticians, General Report 1, Geneva, 2003. BIT, Report of the 17th International Conference of Labour Statisticians, Geneva, 2003. 
for own final use. Although not subject to the law until now, the latter category is liable to benefit from rights with regard to social protection in particular. There are therefore two aspects to the legal issues relating to the informal economy and its transition to the formal economy: that of the enterprise and that of the worker.

It is understood then that the definition of the informal economy, unlike the "shadow economy" (which is compared with GDP), is that it can take the form of a number of jobs. There is, however, another aspect of informality that must be taken into account when considering workers' rights: that of its margins. This is the case of a certain number of employees registered with the social security - therefore in formal employment - but only at the level of the minimum wage. The tacit contract that enables both employers and workers to reduce their contributions is that a part of the wage is paid cash in hand, but this means of course that benefits are reduced accordingly, whether it be sick pay or pension entitlements, in particular. A systematic comparison of pay statistics drawn from the social security records (unfortunately rarely available in developing countries) with the statistics drawn from household surveys is a way of measuring the scale of this phenomenon.

\section{II - WHAT SOCIAL PROTECTION FOR THOSE WORKING IN THE INFORMAL ECONOMY?}

On the basis of the definitions above, we now know that the informal economy represents up to $73 \%$ of non-agricultural employment in sub-Saharan Africa, 65\% in Asia, $57 \%$ in Latin America, $48 \%$ in North Africa and $25 \%$ in the transition economies of Eastern Europe and Central Asia. ${ }^{11}$ These figures would be even higher if agriculture were included since in most developing countries, virtually all agricultural employment is informal. The contribution of the informal sector to GDP represented, for its part, some $55 \%$ in subSaharan Africa (and 25\% of non-agricultural GDP), 32\% in North Africa, 30\% in Latin America and $42 \%$ in India in the 2010 s. ${ }^{12}$ Another way of reading these figures is to consider that these populations and their dependants are not covered by any social protection other than what are commonly known as social safety nets, i.e. welfare limited to the distribution of minimum incomes or food rations, often in return for some form of work, if the safety nets reach them at all.

If we prefer to ignore the terms, such as eradication, elimination and combating, that the informal economy has tended to inspire in the public authorities, sensitive as they are to the unfair competition argument, it is its taxation that has been the subject of the most thought: if this sector accounted for between a third and half of GDP, did that not represent a large taxable base at a time when the latter was shrinking more and more for treasuries short of budgetary income? But the payment of tax, apart from the satisfaction of "being legal" does not translate into immediate, tangible advantages for operators who have generally little benefited and benefit little from access to public services, whether these be education or health, not to mention services that facilitate economic activities (credits, contracts, etc.). In addition, for the tax office, the cost of collection remains prohibitive. That being the case, the same thinking extends to all mandatory levies and social contributions,

11 J. Charmes, «The informal economy worldwide: trends and characteristics Margin" -The Journal of Applied Economic Research, 6, 2, 2012, p. 103-132. ILO, Statistical Update on Employment in the informal Economy. Geneva, 2011

12 J. Charmes, ibid. 
in particular. Adapted taxation systems, such as the Monotax system in Argentina or the Simples system in Brazil, fixed a flat rate of tax based on simple criteria such as electricity consumption or the size of premises (parallel or alternatively to the turnover) and above all, the amount was in full discharge of all other contributions: in particular a certain proportion of the tax paid was automatically directed into the social security system.

In other regions where the social security systems are more fragile and often less widespread outside the public sector, such as in sub-Saharan Africa, the extension of social protection to the informal economy is based on a mutualist system, centred on trades: farmers, artisans, shopkeepers, etc. Mutual societies or cooperatives are set up, often reproducing old forms of community associations and grouping together beneficiary-members. They are overseen by official institutions (public or private, such as NGOs in charge of implementing projects funded by outside donors), guaranteeing the correct management and distribution of the funds collected. Social security levies are linked to savings deposits that are intended to benefit from loans. One original system consists of linking contributions (to health or pension coverage) to the repayment of a loan granted for the purchase of equipment or of an indispensable input (fertiliser for farmers, fuel for hauliers), the idea being to render the payment of regular contributions painless. The Délégation à l'Organisation du Secteur Informe/ ${ }^{13}$ in Togo has thus set up several mutual schemes (farmers, fishermen and livestock farmers, motorcycle-taxi drivers, artisans and shopkeepers, artists and journalists), which provide health coverage to several tens of thousands of beneficiaries. In Côte d'Ivoire, trade-based cooperatives (carpenters, seamstresses, sculptors, potters) have joined health mutual schemes through the intermediation of a European project implemented by an Italian NGO, AVSI. In Ghana, it is again a European project (PlanetFinance) that has raised awareness and organised women collecting and working shea nuts to make shea butter or cream used in top-end cosmetics, so that they can pay into the National Health Insurance System (NHIS). An essential component of the project has consisted of supporting the NHIS itself to reach out to these women in the regions, to listen to their needs, hear their grievances on the way the system currently operates, collect their contributions and update their membership cards. This places the emphasis on contributions being "demandable" (collected by the institution at the citizen's home or workshop) rather being paid voluntarily by the contributor or insured person (that is brought by him/her to the institution's office), a reversal of the norm that has proved to be essential to initiate a virtuous dynamic on the part of the public authorities with regard to the operators of the informal economy, who claim to owe them nothing while expecting nothing of them. A recent report by the Research Network Support Facility ${ }^{14}$ contains an inventory of the various good practices in these fields ${ }^{15}$.

13 DOSI, De la mutualisation à la formalisation. Les actions de la Délégation à l'Organisation du Secteur Informel (DOSI), Lomé, 2015, 18p

14 The Research Network Support Facility (RNSF) is a project funded by the European Union to support the enhancement of livelihoods for people dependent on informal economy and improve social inclusion of marginalised and vulnerable persons. The project relies on the analysis of good practices and lessons learned from past and ongoing development projects. https://europa.eu/ capacity4dev/iesf/dashboard

15 RNSF, Extending coverage: Social protection and the informal economy. Experiences and ideas from researchers and practitioners, Research, Network and Support Facility, ARS Progetti, Rome; Lattanzio Advisory, Milan; and AGRER, Brussels, European Union, 2017. 
This is an area where there is considerable potential for the social and solidarity economy (SSE) to develop as long as it can convince populations, who may have had their fingers burned by previous unfortunate experiences. In fact, the SSE can play a pivotal role in the transition from the informal to the formal economy.

\section{III - TOWARDS A STRATEGY OF TRANSITION FROM THE INFORMAL TO THE FORMAL ECONOMY}

When the International Labour Conference took up the issue of the transition in 2014, it had a duty, due to its statutes and its tripartite composition, to reconcile the logically diverging points of view of the governments, the employers and the workers with respect to a phenomenon over which they have had little or no control. The governments are simultaneously in favour of repression (they have to ensure their regulations are adhered to) and tolerance (self-employment is a solution to the ineffectiveness of job creation policies); the employers are in favour of the eradication of activities that they see as unfair competition without acknowledging that these activities enable them to keep wages low; as for workers' unions, they recognise that these workers - who are not members of their organisations - are entitled to benefit from the basic labour standards defined by the ILO.

After a first discussion of the subject in 2014, it was in June 2015 that Recommendation 204 was adopted, ${ }^{16}$ which would define the framework for future actions on employment policy in developing countries.

Acknowledging that most individuals do not enter the informal economy by choice but by necessity, after failing to find employment in the formal sector, the Recommendation sets itself three objectives: to facilitate the transition of workers and economic units to the formal economy; to promote the creation, preservation and sustainability of enterprises and decent jobs in the formal economy; to prevent the informalisation of formal economy jobs. Such a diversity of situations also implies an equal diversity of strategies and policies to be implemented and a resulting need for coordination.

One of the basic principles is the need to adopt a balanced approach, combining incentives with corrective measures. For formalisation must not break entrepreneurial potential, its creativity, dynamism, skills and capacity for innovation. In addition, it is necessary to punish the circumvention of tax, social and labour laws by enterprises that are seeking to exit from the formal economy.

The guidelines concerning micro-enterprises consist of reducing registration costs and the length of procedures, improving access to services, in particular through information and communication technologies; of reducing the costs of compliance by simplifying methods of calculating and paying taxes and contributions; of facilitating access to public contracts by adapting procedures, introducing quotas and providing adequate training ; of improving access to inclusive financial services, entrepreneurship training and social protection.

16 ILO, Recommendation 204 - Recommendation on the Transition from the Informal to the Formal Economy, adopted by the Conference at its hundred and fourth session, Geneva, 12 June 2015. 


\section{INFORMAL ECONOMY: THE TERMS OF A DEBATE}

Concerning the workers, the issues include: provision of information and assistance: reinforcement of capacities; introduction of effective, easily accessible complaint and appeal procedures; effective application of administrative, civil and criminal sanctions.

A certain number of countries, such as Madagascar, Burkina Faso and Togo are in the process of defining strategies for the transition to the formal economy on the basis of the recommendations in Recommendation 204. Many other countries have taken measures in several of the areas mentioned above (without aiming to coordinate all of them), in particular that of social protection.

\section{CONCLUSION}

Policies in favour of the transition from the informal to the formal economy bring into play many aspects of public policy (taxation, enterprise creation, training, social protection) and the corresponding legislation, in particular social and labour law. Driven by the new commitments of the international community (Sustainable Development Goals), the expansion of universal health coverage and social protection more generally is now on the agenda of most developing countries and the adoption of Recommendation 204 makes it a privileged dimension of the transition strategy. This leads us to consider the necessary changes to social and social security law: how to adapt social contributions to the ability to pay of the new populations covered and the benefits offered to cover their needs, how to distribute the roles between the public and private sectors and also a new player, the social and solidarity economy, for the ambitious objectives of the SDGs can only be achieved by helping the most vulnerable populations to organise against a background in which trust in the State and its institutions is profoundly eroded.

\section{JACQUES CHARMES}

Economist and statistician. IRD Emeritus Research Director at the Population and Development Centre (CEPED) at University Paris Descartes-IRD, Professor of economics at the University of Versailles-Saint Quentin in Yvelines. Research expert for the European Union Research Network Support Facility programme "Support to enhance livelihoods for people dependent on informal economy and improve social inclusion of marginalised and vulnerable persons".

Publications :

'The informal economy worldwide: trends and characteristics' in Margin-The Journal of Applied Economic Research, 6:2 (2012): 103-132.

$\sim$ La jeunesse tunisienne et l'économie informelle, ILO, Tunis, 99p.

$\sim$ J. Charmes and Nidhal Ben Cheikh, (2016), 'Protection sociale et économie informelle en Tunisie, Les défis de la transition à l'économie formelle', CRES and Banque Africaine de Développement, Tunis, 92p. 